This is the author's final, peer-reviewed manuscript as accepted for publication. The publisher-formatted version may be available through the publisher's web site or your institution's library.

\title{
The quality of dietary intake methodology and reporting in child and adolescent obesity intervention trials: a systematic review
}

Tracy Burrows, Rebecca K. Golley, Amina Khambalia, Sarah A. McNaughton, Anthea Magarey, Richard R. Rosenkranz, Margaret Alllman-Farinelli, Anna M. Rangan, Helen Truby, Clare Collins

\section{How to cite this manuscript}

If you make reference to this version of the manuscript, use the following information:

Burrows, T., Golley, R. K., Khambalia, A., Mcnaughton, S. A., Magarey, A., Rosenkranz, R. R., ... Collins, C. (2012). The quality of dietary intake methodology and reporting in child and adolescent obesity intervention trials: a systematic review. Retrieved from http://krex.ksu.edu

\section{Published Version Information}

Citation: Burrows, T., Golley, R. K., Khambalia, A., Mcnaughton, S. A., Magarey, A., Rosenkranz, R. R., ... Collins, C. (2012). The quality of dietary intake methodology and reporting in child and adolescent obesity intervention trials: a systematic review. Obesity Reviews, 13(12), 1125-1138.

Copyright: () 2012 The Authors, obesity reviews @ 2012 International Association for the Study of Obesity

Digital Object Identifier (DOI): doi:10.1111/j.1467-789X.2012.01022.x

Publisher's Link:

http://onlinelibrary.wiley.com/doi/10.1111/j.1467-789X.2012.01022.x/full

This item was retrieved from the K-State Research Exchange (K-REx), the institutional repository of Kansas State University. K-REx is available at http://krex.ksu.edu 


\title{
The quality of dietary intake methodology and reporting in child and adolescent obesity intervention trials: a systematic review.
}

\author{
Tracy Burrows ${ }^{1 *}$, Rebecca K Golley ${ }^{2 *}$, Amina Khambalia ${ }^{3}$, Sarah A.McNaughton ${ }^{4}$, Anthea \\ Magarey $^{5}$, Richard R Rosenkranz ${ }^{6}$, Margaret Alllman-Farinelli ${ }^{7}$, Anna M Rangan ${ }^{7}$, Helen Truby $^{8}$, \\ Clare Collins ${ }^{1}$.
}

${ }^{1}$ School of Health Sciences, Faculty of Health, Priority Research Centre for Physical Activity and Nutrition, University of Newcastle, Newcastle, New South Wales, Australia; ${ }^{2}$ Public Health, School of Health Sciences, Sansom Institute for Health Research, University of South Australia, Adelaide, Australia; ${ }^{3}$ Clinical and Population Perinatal Research, Kolling Institute of Medical Research, University of Sydney at Royal North Shore Hospital, New South Wales, Australia; ${ }^{4}$ Centre for Physical Activity and Nutrition Research, School of Exercise and Nutrition Sciences, Deakin University, Burwood, Victoria, Australia; ${ }^{5}$ Nutrition and Dietetics, Flinders University, Adelaide, SA, Australia; ${ }^{6}$ Department of Human Nutrition, Kansas State University, Manhattan, KS, USA ${ }^{7}$ Nutrition and Metabolism, School of Molecular Bioscience, The University of Sydney, NSW, Australia; ${ }^{8}$ Nutrition and Dietetics, Monash University, Clayton, Victoria, Authors are part of the food and nutrition stream of the Australian Child and Adolescent Obesity Research Network (ACAORN). This is a network established to foster and coordinate research collaboration among Australian and New Zealand child and adolescent obesity researchers.

Author Contributions: *Co-first authors contributed equally to this work. All authors provided input to data collection and preparation of manuscript. All authors have approved the final article. None of the authors had any financial support or relationships that may pose conflict of interest

\section{Address Correspondence to:}

Dr Tracy Burrows

PhD, BHSc (N\&D), GTTT, Adv APD

School of Health Sciences, Faculty of Health, University of Newcastle, University Drive, Callaghan, Newcastle, NSW, Australia, 2308 
Ph. +61 249215514

Fax +61249216984

Email Tracy.burrows@newcastle.edu.au

Running Head: The quality of dietary intake methods reporting

Abstract word count: 229

Manuscript word count: 3613

Number of figures: 3

Number of tables: 1

Key words: diet, nutrition, methodology, obesity, overweight, children, interventions, systematic review

Disclosure of interest: The authors have no conflicts of interest to disclose.

Acknowledgements: We wish to thank the librarian Debbie Booth, University of Newcastle who designed the electronic search strategies, Ms Lucy Bell, University South Australia for assistance with screening and data extraction and Ms Roberta Asher for pilot data extraction and study retrieval. Funding was received from the Australian Child and Adolescent Obesity Research Network. RKG was supported by a National Health and Medical Research Council (NHMRC) Public Health Postdoctoral Fellowship (ID 478115). AK is funded by an Australian National Health and Medical Research Council (NHMRC) Centers for Research Excellence (APP1001066). SAM is supported by an Australian Research Council Future Fellowship (FT100100581). CC is support by an NHMRC Career Development Fellowship. 


\section{ABSTRACT}

Background: Assessing dietary intake is important in evaluating childhood obesity intervention effectiveness.

Purpose: To evaluate the dietary intake methods and reporting in intervention studies that included a dietary component to treat overweight or obese children.

Methods: A systematic review of studies published in the English language, between 1985 and August 2010 in health databases.

Results: The search identified 2295 papers, of which 335 were retrieved and 31 met the inclusion criteria. Twenty-three studies reported energy intake as an outcome measure, 20 reported macronutrient intakes and 10 studies reported food intake outcomes. The most common dietary method employed was the food diary $(n=13)$, followed by 24-hour recall $(n=5)$, food frequency questionnaire (FFQ) $(n=4)$ and, dietary questionnaire $(n=4)$. The quality of the dietary intake methods reporting was rated as 'poor' in 15 studies (52\%) and only three were rated as 'excellent.' The reporting quality of FFQs tended to be higher than food diaries/recalls.

Conclusions: Deficiencies in the quality of dietary intake methods reporting in child obesity studies were identified. Use of a dietary intake methods reporting checklist is recommended. This will enable the quality of dietary intake results to be evaluated, and an increased ability to replicate study methodology by other researchers. 


\section{BACKGROUND}

Dietary intake is a major determinant in the development, prevention and management of child and adolescent overweight and obesity. ${ }^{12,3}$ There are limited published data that report on children's dietary intake in the context of obesity interventions. In a 2006 systematic review of child obesity treatment studies that included a dietary intervention component, 23 of 37 randomized controlled trials (RCTs) indicated that changes in dietary intake were measured. ${ }^{4}$ However, only 11 studies actually reported dietary outcomes. ${ }^{4}$

The lack of reporting of dietary outcomes is likely due to the challenges of measuring dietary intake, particularly in children and adolescents. ${ }^{5}$ A number of issues need to be considered when assessing dietary intake. This includes whether a comprehensive assessment of usual diet is required versus specific food components or dietary patterns; as well as consideration of subject burden, cost, administrative and analytic burdens. ${ }^{6}$ These issues are discussed in detail elsewhere. ${ }^{1,}$

${ }^{5}$ Additionally, there are many methods to assess dietary intake each with advantages and disadvantages, including threats to deriving reliable and valid estimates of energy, food, or nutrient intake. $^{1,5}$

Good quality reporting of dietary intake methods is an important part of being able to replicate studies, interpret dietary intake findings and consider potential measurement bias. ${ }^{6}$ There are no universal recommendations to guide adequate reporting of dietary methods or the validity of dietary assessment methods. However the checklist by Nelson and colleagues provides an overview of the details required. ${ }^{7}$ Similarly the score developed by Serra-Majem and colleagues provides a means of evaluating the quality of dietary intake validation studies. ${ }^{8}$ To our knowledge, no research to date has critiqued the dietary assessment methods and reporting used in child obesity intervention studies that include an outcome measure of dietary intake.

Therefore the aim of this review was to evaluate the quality of reporting of dietary intake methods in intervention trials for treatment of overweight or obesity in children and adolescents that included a dietary component and reported a dietary outcome. 


\section{METHODS}

This systematic review followed a prospectively prepared protocol, and is reported using the PRISMA reporting guidelines for systematic reviews. ${ }^{9}$

\section{Search strategy}

A two-phased search strategy was undertaken to identify studies in the English language published between 1985 and August 2010. With the expertise of a librarian, investigators conducted an initial search in MEDLINE and Cumulative Index to Nursing and Allied Health Literature (CINAHL) to establish appropriate search terms. A second systematic search of all relevant databases (PREMEDLINE/MEDLINE, Cochrane Library, EMBASE (Excerpta Medica Database), CINAHL, Web of Science, Scopus and PsycINFO) was performed using key words. These were: dietetic, diet, nutrition, healthy eating and dietary intervention, paediatric (pediatric), child, adolescent, family, parent, school, overweight, obesity, intervention, weight control or weight management or weight loss or healthy weight. An example of a full search strategy is presented in

Table S1. Full electronic search strategies are available upon request. Electronic searches were supplemented by cross-checking reference lists of relevant publications.

\section{Selection criteria}

To be eligible for inclusion, studies needed to: be a RCT or controlled clinical trial; examine an intervention for treatment of overweight and/or obesity that included a dietary component; target children/ adolescents (defined for this review as $<20$ years of age) who were defined as overweight or obese; and report a measure of dietary intake as an outcome (i.e. energy intake, macro and/or micronutrient intakes, grams of food groups/ items, percentage of energy from foods groups/ items, frequency of consumption of foods). Studies that only included a dietary-related outcome (i.e. measures of disordered eating, food habits, or dietary knowledge) were excluded. To limit the heterogeneity of studies reviewed, studies that were of overall poor study methodology were excluded. Overall study quality was assessed using the standardised critical appraisal tool from the American Dietetic Association (ADA). ${ }^{10}$ Ten quality questions were rated (yes/no) spanning: clarity 
of research question, selection bias, randomisation, drop out, blinding, clarity of intervention description, validity of measures, appropriateness of statistical analyses, conclusions drawn, and funding sources. An overall quality rating was assigned: Positive if five or more questions were rated "Yes" (including questions 2, 3, 6, 7); Neutral if questions 2, 3, 6, and 7 were rated "No";

Negative if six or more questions were rated "No" or two or more of questions 2, 3, 6, 7 were rated "No". Only studies rated positive or neutral were included in the review.

\section{Selection strategy and procedures}

Articles were assessed for eligibility independently by two investigators in two stages; the first screening stage involved titles and abstracts, and the second involved the full text. In case of discrepancy between the investigators at stage one screening, the paper was automatically included into stage two screening. Any discrepancies at stage two screening were resolved through discussion among three investigators.

\section{Critical appraisal}

Dietary assessment methods and reporting quality assessment were performed independently by two reviewers using a checklist developed specifically for this review (Table S2). The checklist was informed by the dietary assessment methods checklist of Nelson and colleagues ${ }^{7}$ and the EURReca (European Micronutrients Recommendations Aligned) scoring system. ${ }^{8}$ The review checklist consisted of six components: methodology validated in similar population, appropriate validation statistics used, data collection quality, reporting of scoring or details of food composition database, and two method specific components (e.g. scale frequency, multiple recall days, seasonality considered). A summary score of the components was calculated. The maximum score was seven and studies were rated as: poor $(\leq 2)$, acceptable $(\leq 2.5-\geq 3.5)$, good $(\geq 3.5-\leq 5)$ or excellent $(\geq 5.0)$.

For those studies which referenced a validation study for the dietary assessment method, the reference(s) were retrieved and were assessed for study design (validation or reliability study), 
appropriateness of the validation study population, their comparative (reference) method and the statistical analysis performed.

\section{Data extraction and analysis}

Data were extracted into standardised tables by one investigator and checked for completeness and accuracy by a second. A meta-analysis was not possible, given the heterogeneity of the intervention strategies and outcomes measured. Data synthesis comprised grouping studies by dietary assessment method and comparing in terms of study characteristics and dietary assessment methods reporting quality. 


\section{RESULTS}

\section{General description of included studies}

The search identified 2295 papers of which a total of 31 papers met the review inclusion criteria (Figure 1). The most common reason for exclusion was study population $(n=125)$, and 95 studies were excluded as no dietary intake outcomes were reported. The majority of included studies were RCTs ( $\mathrm{n}=27$ ) (Table 1) and were published from 2007, with no retrieved papers published prior to 2000. Eighteen studies were conducted in the Americas ${ }^{11-28}$, four were conducted in Europe, ${ }^{29-32}$, four in Mediterranean and Middle Eastern countries, ${ }^{33-36}$ and three in Australia. ${ }^{37-39}$ Twelve studies were conducted in a community setting, ${ }^{11-13,15,16,18,20-22,27,28,37}$ seven in hospitals, ${ }^{14,17,29-31,33,35}$ four in universities, ${ }^{19,24,26,36}$ and four in primary health care settings. ${ }^{25,34,38 \text {, }}$ ${ }^{39}$ Six studies targeted children less than 10 years of age, ${ }^{11,17,23,37-39} 13$ studies focused on older children, ${ }^{12-16,21,25-28,31,40,41}$ while 12 studies included both younger and older children (Table 1). The number of study participants ranged from 16 to 258 , with most studies including between 20 and 50 participants per group (Table 1).

Interventions were heterogeneous and included various combinations of the cornerstones of child weight management; diet, physical activity, and behaviour modification (Figure 2). The group comparison was diet versus physical activity in nine studies; ${ }^{12,13,16,17,19,26,37,41}$ a comparison of different dietary approaches in seven studies, ${ }^{14,21,27-29,31,37}$ and alternative delivery approaches in

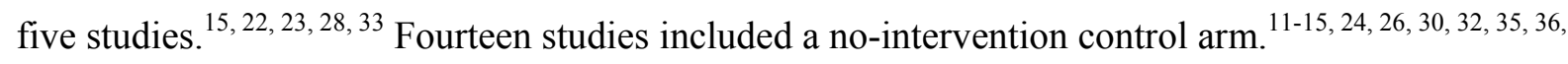
${ }^{38-40}$. Most studies had short-term interventions, mean 13 weeks (range 6 to 25) (Table 1). Followup was generally limited to the end of the intervention ${ }^{11-13,15,17-19,27,28,36,40}$ and varied between eight weeks ${ }^{18}$ and two years. ${ }^{17}$

\section{Dietary assessment methods and reporting}

Twenty three of the 31 studies reviewed reported energy intake as an outcome measure, and 20 reported macronutrient intakes (Table 1). In contrast, only 10 studies reported food group intake outcomes. The most common method for assessing dietary intake was a food diary/record $(\mathrm{n}=13$ 
studies), with five using 24 hour records/ recalls, four using food frequency questionnaires (FFQ i.e. questionnaires focusing specifically on assessment of frequency of food intake) and four using dietary questionnaires (Figure 2). The remaining five studies used multiple dietary assessment or other methods.

The reporting of the dietary assessment methods was rated as 'poor' for 15 of the 31 studies (Table 1). A registered dietitian was reported as administering the dietary assessment method in 10 studies, with a further 11 studies reporting use of personnel who had received some training in dietary assessment. The reporting of dietary methods was generally limited by a lack of information on the instrument quality and validity, the qualifications of the person who administered the dietary assessment, and the food composition database that was used to derive energy and nutrient intakes. Of the 31 studies, 11 studies made reference to a dietary validation study for the dietary assessment tool used in the study $16,17,20,25,27,28,32,33,35-37$. Of the studies that did not cite a validation reference, 11 used a food record, either weighed or estimated. The four studies using a food record that did reference a validation study all cited the same reference. One validation study was conducted in an adult population, limiting its applicability to the population in which it was used.

Among the referenced validation studies the test dietary intake assessment method was compared with another dietary method, with the exception of three studies which used objective standards. Two studies compared a food diary or a diet history with Doubly Labelled Water (DLW) and a FFQ was compared against biomarkers of fruit and vegetable intake.

The most common statistical approach used to compare two methods was correlation coefficients ( $\mathrm{n}=8$ studies). Three studies compared mean intake by the two methods using T-tests. Three studies used Bland-Altman plots to assess the level of agreement between methods, and one used Kappa statistic. Correlation coefficients for FFQs were modest and ranged between 0.26 and 0.63 and between 0.50 and 0.6 for 24 hour recalls. Repeatability was only assessed in three studies, although one was conducted in adults and not the child population where it was applied. 
The dietary assessment methods reporting for studies using a food diary/record was generally poor (Figure 3), with only three studies rated as good/ excellent ${ }^{32,33,35}$. However seven did report that the food diary/records were administered by a trained person (Figure 3). Most of the studies using 24-hour recalls were rated as good for dietary methods reporting quality and tended to be administered by a registered dietitian (Figure 3). Studies that used multiple dietary intake methods used 24-hour recalls in addition to either a food frequency questionnaire $(n=2)$ or a diet history interview ( $\mathrm{n}=1)$. Studies using dietary questionnaires were more variable (Figures 2 and 3). The validity of the dietary questionnaires was not addressed in any of the studies and none were reported as being administered by trained staff. All the studies utilising dietary questionnaires were rated as poor for dietary methods reporting (Table 1).

\section{DISCUSSION}

\section{Principal findings}

To the authors' knowledge, this is the first systematic review to evaluate the quality of dietary intake methods reporting in intervention studies evaluating childhood obesity interventions that included a dietary component. Studies were only selected for inclusion in the review if their overall study design quality was high. Despite this, there were limitations in the dietary intake methods detail provided in the majority of studies reviewed. The quality of dietary assessment methods reporting was rated as 'poor' in 15/31 studies reviewed and only three were rated as 'excellent'. ${ }^{20,29,37}$ This is surprising given dietary intake is commonly a key focus of intervention for both treatment and prevention of childhood obesity. Poor dietary intake methods' reporting has implications for a reader's ability to replicate studies, interpret dietary intake findings and consider potential measurement bias.

Choice of dietary assessment method did appear to be related to the quality of the dietary assessment methods reporting. The reporting quality of studies that used food frequency questionnaires tended to be rated as 'excellent' or 'good', compared to studies that used 24-hour 
recalls or food diaries. These findings may reflect the high degree of structure associated with food frequency questionnaires which may make it easier to report method details appropriately or that FFQs can be quite varied and specific to foods/population groups which require more detail. In comparison, food recalls and diaries are complex and their administration involves a number of detailed steps. This complexity may make it difficult to comprehensively but concisely provide sufficient detail on these methods when word count for the overall article is limited. Twenty-four hour recalls may also have a perception that this approach is a standardised methodology and does not require further detail. The dietary assessment methods reporting of dietary questionnaires was particularly poor. This may reflect that dietary questionnaires themselves are a relatively recent addition to the dietary assessment methods repertoire and lack rigorous testing. There may also be the perception that nutrition experts need not be involved in their development and validation.

The review highlights the limited use or availability of validated tools to assess dietary intake in paediatric populations. Dietary intake assessment is complex and all methods have a number of threats to validity and reliability, including those considered 'gold standard' such as weighed food records and 24 hour recalls. ${ }^{5}$ It is important to use methods that are age-appropriate and have been developed, piloted and validated for assessing children's dietary intake. Without adequate piloting in the study population, or use of methods that have been validated in a similar study population, it is not possible to interpret dietary intake findings. For example, were the changes in dietary intake (or lack thereof) observed due to the intervention or measurement error? Choosing existing validated tools or undertaking a validation sub-study needs to be considered when planning a study. It is also important to report or reference the validation details when reporting dietary intake outcomes.

Selection of the most appropriate dietary assessment tool depends on many factors, including type of information needed (i.e. foods, nutrients, or specific dietary behaviours), the level of accuracy required, the research constraints (i.e. money, time, staff and respondent characteristics) and the suitability of that method to the study design. ${ }^{42}$ None of the studies provided a rationale for 
their choice of dietary assessment method. The most common method for assessing dietary intake was the food diary/record, whereby the respondent (or parent, in case of children) recorded the foods and beverages and the amounts of each consumed over one or more days. Although this method was commonly used and is considered a gold standard its accuracy is questionable ${ }^{43}$. Researchers using food records in child obesity interventions should take particular care to ensure quality use within a study and quality reporting of the method. Only 10 studies reported actual changes in food consumption, with most reporting outcomes such as energy and macronutrients. This lack of food-based outcome data makes development of practical food-based guidelines for obesity interventions for children and adolescents difficult. The use of 24 hour recalls or FFQs appear to provide the most meaningful results in terms of study quality and flexibility for a range of diet outcomes. Technology-assisted versions of these methods may increase the feasibility of incorporating these methods into future child obesity intervention trials by reducing participant and researcher-burden.

The checklist used to rate the quality of the dietary assessment methods reporting was developed for the purposes of the present review. It was informed by the "Checklist for the Methods Section of Dietary Investigations" which was proposed by the UK Nutritional Epidemiology Group ${ }^{7,44}$ in the early 1990s as a guide for reporting on nutrition. Results of this review indicate infrequent application of this checklist or similar principles, and highlights the need for journal editors to set higher standards for studies reporting dietary methods in the context of child obesity interventions. This will encourage authors to fully describe their dietary methods and incorporate meaningful and valid measures of dietary intake. ${ }^{1,7,43}$

The majority of studies that did not reference a dietary validation study used food records, perhaps because this is considered the closest to a 'gold standard'. However, given the limitations associated with all dietary assessment methods, the same reporting standards should apply to food records, including transparent reporting of validity properties in a similar population. 
The majority of validation studies used correlation statistics which indicate whether two methods are associated. Associations between dietary methods may be an artefact of correlated errors and correlation coefficients of the magnitude observed in this review (around 0.6) suggest that $\sim 40 \%$ of individuals would be misclassified by one method compared to the other ${ }^{45}$. C. deMoor et al ${ }^{46}$ suggest a correlation coefficient of 0.9 or higher is needed to avoid misclassification bias. We would recommend alternative statistical approaches be reported in validation studies. Techniques such as Bland and Altman plots or methods assessing misclassification (e.g. kappa statistic) provide more useful information on agreement between methods and are more transparent in potential error or bias associated with different dietary assessment methods. Repeatability and sensitivity to detecting change of dietary assessment method was rarely assessed. This is particularly important in the context of child obesity intervention studies and should be considered or evaluated when selecting dietary assessment methods in future studies.

\section{Strengths and limitations}

Strengths of this systematic review include an extensive literature search, rigorous adherence to a predefined protocol and use of an evidence-based set of items for reporting in systematic reviews. ${ }^{9}$ In addition, this review was conducted using systematic and standardised search methodologies ${ }^{9}$ in/among several electronic databases to identify eligible papers. A limitation is that the search strategy only identified studies published in English in the peerreviewed literature. Studies among children and adolescents reported in other forums, including trade journals, conferences, and committee meetings were not included and pose a possible publication bias. While most of the high quality scientific literature is published in peer-reviewed sources, the poor quality or negative findings associated with dietary intake data raises the potential of publication bias. However, this only reinforces the need to consider carefully the collection and reporting quality when dietary intake is a study outcome.

\section{Implications}


This systematic review highlights the need for improvement in the quality of dietary intake assessment methods and reporting in childhood obesity studies. Like many other areas of scientific research, such as the reporting of randomized controlled trials ${ }^{47}$ or systematic reviews, ${ }^{48}$ results of this review reinforce the need for transparent and comprehensive reporting of dietary methods. Increased quantity and quality of information on the dietary measures, interventions and outcomes used in childhood obesity studies will further knowledge on the dietary treatments that promote weight loss. Further, developing an evidence base for making public health and clinical decisions requires assessing the quality and outcomes of individual studies. However, to make the best use of dietary intake information in quantitative research syntheses requires transparent reporting of the methods and outcomes, with sufficient detail and clarity to allow evaluation of the differences and similarities among studies. ${ }^{49}$ As novel dietary assessment methods which utilise new technologies such as the Internet or mobile phones become available ${ }^{50,51}$, this review will need to be updated and compare the studies using these newer methods to the older and see if it changes what can be learnt from the intervention studies about what aspects of diet are amenable to change.

\section{Recommendations}

Assessing the diets of children and adolescents presents unique methodological challenges. There are age related limits on what aspects of diet can be reported due to child cognitive abilities or using parent proxies who may or may not know what is consumed by the child for all or part of the day. In addition, dietary outcomes in overweight and obesity studies are often secondary outcomes and may be given less attention and resources. However, adoption of the following recommendations would improve dietary methods and reporting quality in future studies;

- Twenty-four hour recalls or FFQs provide good quality dietary assessments. The choice between methods should be guided by the research question and outcomes of interest and consideration of the inherent strengths and limitations of any dietary assessment method. 
Consideration should be given for using FFQs with another method such as 24 hour recall or WFR as a comparative method in at least a population sub sample.

- The validity properties of the method selected should be known in child and adolescent (and preferably overweight/obese) populations. Studies are needed to better understand the validity of WFR, 24hour recalls and dietary questionnaires in the context of obesity interventions in children and adolescents.

- To ensure that study findings are interpretable and replicable, special attention is needed to improve the reporting of dietary method validity details or reference, the qualifications or training of those who administer the dietary assessment, and the food composition database used to derive energy and nutrient intakes.

There are excellent resources readily available to investigators to ensure that the appropriate dietary tool is selected, administered properly and is adequately described in the study methods. These include the Australian Child and Adolescent Obesity Research Network online decision tree which can assist researchers in the selection of appropriate dietary intake methodologies for studies in the context of child obesity, ${ }^{52}$ a detailed online interactive decision matrix provided by the Medical Research Council, ${ }^{53}$, the checklist by Nelson et al. which is a must for researchers reporting studies that include assessment of dietary intake. ${ }^{7}$ and existing publications in measuring dietary intake in children and adolescents in the context of overweight and obesity ${ }^{1,5}$.

\section{CONCLUSION}

The goal of the present review was to provide an overview of the state of dietary assessment methods reporting in childhood obesity intervention studies to inform future study design and reporting. Results indicate that authors, reviewers and journal editors need to ensure more transparent and consistent reporting of dietary methods used in childhood obesity trials if the quality of study reporting is to be improved. In particular, reporting of dietary methods can be improved if 
investigators provide information on the instrument validity, the qualifications or training of those who administer the dietary assessment, and the food composition database that was used to derive energy and nutrient intakes. Use of the checklist presented in table S2 will help to achieve this. 
Table 1: General Study description of included randomized controlled trials

\begin{tabular}{|c|c|c|c|c|c|c|c|c|c|}
\hline \multirow[t]{2}{*}{ Reference } & \multirow{2}{*}{$\begin{array}{l}\text { Country, } \\
\text { Setting }\end{array}$} & \multicolumn{3}{|c|}{ Participants } & \multirow{2}{*}{$\begin{array}{l}\text { Study } \\
\text { quality }^{2}\end{array}$} & \multirow[t]{2}{*}{ Study Arms } & \multirow{2}{*}{$\begin{array}{l}\text { Intervention duration } \\
\text { and intensity, } \\
\text { Follow up (retention) }\end{array}$} & \multirow{2}{*}{$\begin{array}{l}\text { Dietary } \\
\text { Reporting } \\
\text { Quality }^{3}\end{array}$} & \multirow[t]{2}{*}{ Dietary Measures } \\
\hline & & $\mathbf{N}$ & $\begin{array}{l}\text { Age } \\
\text { (years) }\end{array}$ & $\begin{array}{l}\text { Weigh } \\
\text { t } \\
\text { status }\end{array}$ & & & & & \\
\hline $\begin{array}{l}\text { Albala et } \\
\text { al } 2008^{11}\end{array}$ & $\begin{array}{l}\text { Chilean } \\
\text { Commun } \\
\text { ity }\end{array}$ & 98 & $8-10$ & $\begin{array}{l}\text { OW/OB } \\
\text { (CDC } \\
\text { BMI } \\
\text { \%tile) } \\
\end{array}$ & Positive & \begin{tabular}{|ll}
$(1)$ & DP \\
$(2)$ & True Control
\end{tabular} & $\begin{array}{l}16 \text { weeks, weekly home } \\
\text { visits and milk delivery } \\
16 \text { weeks (end-I, 94\%) }\end{array}$ & Poor & $\begin{array}{l}\text { FFQ baseline and } 16 \text { weeks } \\
\text { with mothers present }\end{array}$ \\
\hline $\begin{array}{l}\text { Burrows et } \\
\text { al } 2008^{37}\end{array}$ & $\begin{array}{l}\text { Australia } \\
\mathrm{n} \\
\text { Commun } \\
\text { ity }\end{array}$ & 165 & $5-9$ & $\begin{array}{l}\text { OW/OB } \\
\text { (IOTF) }\end{array}$ & Positive & $\begin{array}{l}\text { (1) P + FS + HE + } \\
\text { NS + DA (parent) } \\
(2) \quad \text { PA + NP (child) } \\
\text { (3) PA + NP + P + FS } \\
+\mathrm{HE}+\mathrm{NS}+\mathrm{DA} \text { (parent \& } \\
\text { child combined) }\end{array}$ & $\begin{array}{l}6 \text { months, } 10 x 2 \text { hour } \\
\text { weekly group sessions }+ \\
3 x \text { monthly phone calls } \\
6 \text { months (end-I, 70\%), } 12 \\
\text { months (FU 64\%) }\end{array}$ & Excellent & $\begin{array}{l}\text { 135-item semi-quantitative } \\
\text { FFQ }\end{array}$ \\
\hline $\begin{array}{l}\text { Davis et al } \\
2009 \mathrm{a}^{12}\end{array}$ & $\begin{array}{l}\text { USA } \\
\text { Latino } \\
\text { Commun } \\
\text { ity }\end{array}$ & 54 & $14-18$ & $\begin{array}{l}>85^{\text {th }} \\
\text { BMI } \\
\text { \%tile }\end{array}$ & Positive & $\begin{array}{ll}\text { (1) } & \mathrm{HE}+\mathrm{BT} \\
\text { (2) } & \mathrm{HE}+\mathrm{BT}+\mathrm{PA} \\
\text { (3) } & \text { True Control }\end{array}$ & $\begin{array}{l}16 \text { weeks, } 4 x \text { motivational } \\
\text { interviews }+\$ 25 \text { grocery } \\
\text { certificate }+ \text { bi-weekly } \\
60 \text { min strength training } \\
16 \text { weeks (end-I, } 100 \% \text { ) }\end{array}$ & Acceptable & $\begin{array}{l}\text { 3-day food record with } \\
\text { instructions Given measuring } \\
\text { cups and rulers to aid in } \\
\text { accurate reporting. }\end{array}$ \\
\hline $\begin{array}{l}\text { Davis et al } \\
2009 b^{13}\end{array}$ & $\begin{array}{l}\text { USA } \\
\text { Latino } \\
\text { Commun } \\
\text { ity }\end{array}$ & $\begin{array}{l}50 \\
\text { (girls } \\
\text { only) }\end{array}$ & $14-18$ & $\begin{array}{l}>85^{\text {th }} \\
\text { BMI } \\
\% \text { ile }\end{array}$ & Positive & 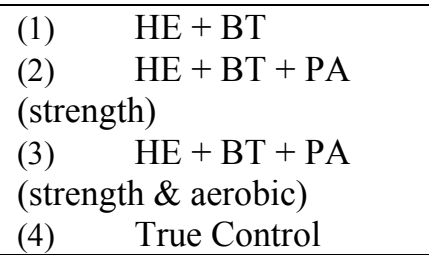 & $\begin{array}{l}16 \text { weeks, } 4 \times \text { motivational } \\
\text { interviewing, } 2 \times 60 \text { min } \\
\text { strength training, } 2 \times 60 \\
\text { min aerobic training } \\
16 \text { weeks (end-I, 82\%) }\end{array}$ & Acceptable & As above \\
\hline $\begin{array}{l}\text { Ebbeling } \\
\text { et al } \\
2003^{14}\end{array}$ & $\begin{array}{l}\text { USA } \\
\text { Hospital }\end{array}$ & 16 & $13-21$ & $\begin{array}{l}\text { OB } \\
\text { (BMI>9 } \\
5^{\text {th } \% \text { ile })}\end{array}$ & Positive & $\begin{array}{l}(1) \quad \mathrm{DP}(\text { red GlyLoad }) \\
+\mathrm{BT}+\mathrm{PA}+\mathrm{NP} \\
(2) \quad \mathrm{DP}(\text { red fat })+\mathrm{BT} \\
+\mathrm{PA}+\mathrm{NP}\end{array}$ & $\begin{array}{l}6 \text { months, } 12 \text { dietary } \\
\text { counselling sessions }+2 \\
\text { follow up dietary } \\
\text { counselling sessions } \\
12 \text { months (FU, 87.5\%) } \\
\end{array}$ & Acceptable & $\begin{array}{l}\text { 7-day food record, Measuring } \\
\text { utensils used to educate } \\
\text { accurate appraisal of portion } \\
\text { sizes. }\end{array}$ \\
\hline $\begin{array}{l}\text { Ebbeling } \\
\text { et al } \\
2006^{15}\end{array}$ & $\begin{array}{l}\text { USA } \\
\text { Schools } \\
\text { Commun } \\
\text { ity }\end{array}$ & 103 & $13-18$ & $\begin{array}{l}\mathrm{N}(53- \\
58 \%) / \\
\mathrm{OW}\end{array}$ & Positive & $\begin{array}{l}\text { DP } \\
\text { True Control }\end{array}$ & $\begin{array}{l}25 \text { weeks Beverages home } \\
\text { delivered weekly } \\
25 \text { weeks (end-I, 100\%) }\end{array}$ & Poor & $2 \times 24 \mathrm{hr}$ recall \\
\hline $\begin{array}{l}\text { Ellis et al } \\
2010^{16}\end{array}$ & $\begin{array}{l}\text { USA } \\
\text { African } \\
\text { American }\end{array}$ & 49 & $12-17$ & $\begin{array}{l}\text { OB } \\
(\mathrm{BMI} \\
>95^{\mathrm{th}} \\
\% \text { ile } \\
\end{array}$ & Neutral & $\begin{array}{l}(1) \quad \mathrm{DP}+\mathrm{HE}+\mathrm{NS}+ \\
\mathrm{PA}+\mathrm{SB}+\mathrm{FS}+\mathrm{BT}+\mathrm{P} \\
+\mathrm{NE}\end{array}$ & $\begin{array}{l}6 \text { months Twice per week } \\
\text { (control group weekly) } \\
7 \text { months (end-I, 84\%) } \\
\end{array}$ & Poor & $\begin{array}{l}\text { Questionnaire, Fat and fibre } \\
\text { behaviour rated on a } 28 \text { item } \\
\text { questionnaire ( } 4 \text { point, scale }\end{array}$ \\
\hline
\end{tabular}




\begin{tabular}{|c|c|c|c|c|c|c|c|c|c|}
\hline & & & & & & $\begin{array}{l}\text { PA (Parent only sessions) } \\
\text { (3) WL Control }\end{array}$ & $\begin{array}{l}16 \text { weeks (end-I, 87\%),10 } \\
\text { months (f'up 76\%) }\end{array}$ & & \\
\hline $\begin{array}{l}\text { Krebs et al } \\
2010^{21}\end{array}$ & $\begin{array}{l}\text { USA } \\
\text { Commun } \\
\text { ity }\end{array}$ & 46 & $12-18$ & $\begin{array}{l}\text { OB } \\
(\geq 175 \% \\
\text { IDW })\end{array}$ & Positive & $\begin{array}{l}(1) \quad \text { DP (High Pro, Low } \\
\text { CHO })+\mathrm{NP}+\mathrm{PA} \\
(2) \quad \mathrm{DP}(\text { Low Fat })+ \\
\mathrm{NP}+\mathrm{PA}\end{array}$ & $\begin{array}{l}13 \text { weeks, Fortnightly } \\
\text { clinic visits } \\
13 \text { wks (end-I, 72\%),24 wk } \\
\text { (FU 1, 59\%), } 36 \text { wks (FU } \\
2,48 \%)\end{array}$ & Poor & $\begin{array}{l}\text { 3-day food record, multiple } \\
\text { occasions ( } 3-14 \text { days recoded } \\
\text { for each subject, average } 8.1 \\
\text { days) }\end{array}$ \\
\hline $\begin{array}{l}\text { McCallum } \\
\text { et al } 2007 \\
38\end{array}$ & $\begin{array}{l}\text { Australia } \\
\text { Primary } \\
\text { Care }\end{array}$ & 163 & $5-9$ & $\begin{array}{l}\text { OW/OB } \\
\text { (IOTF) }\end{array}$ & Positive & $\begin{array}{ll}\text { (1) } & \text { BT + FS + NP } \\
\text { (2) } & \text { True Control }\end{array}$ & $\begin{array}{l}12 \text { weeks Parents attended } \\
4 \text { consultations over a } 12- \\
\text { week period } \\
9 \text { months (FU, 93\%),12 } \\
\text { months (FU, 90\%) }\end{array}$ & Poor & $\begin{array}{l}\text { 4-day food record, listed } 14 \\
\text { foods, parent reported } \\
\text { consumption as none, once or } \\
\text { twice or more. }\end{array}$ \\
\hline $\begin{array}{l}\text { Nemet et } \\
\text { al } 2005^{35}\end{array}$ & $\begin{array}{l}\text { Israel } \\
\text { Hospital }\end{array}$ & 54 & $6-16$ & $\mathrm{OB}$ & Positive & $\begin{array}{ll}(1) & \mathrm{FS}+\mathrm{DA}+\mathrm{NP}+ \\
\mathrm{HE}+\mathrm{NS}+\mathrm{NE}+\mathrm{PA} \\
(2) \quad \text { Control }\end{array}$ & $\begin{array}{l}3 \text { months(1) I group: } 6 \\
\text { consults over } 3 \text { mths, } 30- \\
45 \text { mins each, parents } \\
\text { involved; } 2 \times 1 \text { fr exercise } \\
\text { training sessions/wk } \\
\text { C group: } 1 \text { nutritional } \\
\text { consultation with PA } \\
\text { advice } \\
\text { 3-months (end-I, } 80 \% \text { ), } \\
\text { 12-months (FU 67\%) }\end{array}$ & Good & 2-day food record \\
\hline $\begin{array}{l}\text { Nemet et } \\
\text { al } 2006^{36}\end{array}$ & $\begin{array}{l}\text { Israel } \\
\text { Hospital }\end{array}$ & 24 & $6-16$ & $\begin{array}{l}\text { OB } \\
\text { (BMI } \\
>95^{\text {th }} \\
\% \text { ile) }\end{array}$ & Neutral & $\begin{array}{l}\text { (1) } \quad \mathrm{FS}+\mathrm{DA}+\mathrm{NP}+ \\
\mathrm{HE}+\mathrm{NS}+\mathrm{NE}+\mathrm{PA} \\
(2) \quad \text { Control }\end{array}$ & $\begin{array}{l}3 \text { months } 14 \text { weekly } \\
\text { meetings ( } 8 \text { with parent } \\
\text { only bi weekly) } 60- \\
90 \text { mins, } 12 \text { sessions with } \\
\text { children }+6 \text { with parents. } \\
2 \text { x per week } 1 \text { hour } \\
\text { exercise training }+1 \text { x } 45 \\
\text { min movement therapy } \\
\text { session } \\
3 \text { months (end-I, } 100 \%)\end{array}$ & Poor & $\begin{array}{l}2 \times 24 \mathrm{hr} \text { recall, One weekday } \\
\text { and one weekend day at } \\
\text { baseline and not clear at } \\
\text { follow up. }\end{array}$ \\
\hline $\begin{array}{l}\text { Park et al } \\
2007^{40}\end{array}$ & $\begin{array}{l}\text { Korea } \\
\text { School }\end{array}$ & 44 & $13-15$ & $\begin{array}{l}\text { OB } \\
(\mathrm{BMI} \\
>95^{\mathrm{th}} \\
\% \text { ile })\end{array}$ & Positive & $\begin{array}{ll}\text { (1) } & \text { PA + BT } \\
\text { (2) } & \text { True Control }\end{array}$ & $\begin{array}{l}12 \text { weeks PA (walking) - } 6 \\
\text { days/week supervised } \\
\text { sessions, DL \& BT -once } \\
\text { per week } \\
12 \text { weeks (end-I, 91\%) }\end{array}$ & Poor & $\begin{array}{l}\text { 3-day food record, } 2 \\
\text { weekdays and } 1 \text { weekend day. } \\
\text { Several practice sessions on } \\
\text { measuring cup, spoon, and }\end{array}$ \\
\hline
\end{tabular}




\begin{tabular}{|c|c|c|c|c|c|c|c|c|c|}
\hline & & & & & & & & & ruled paper. \\
\hline $\begin{array}{l}\text { Raynor et } \\
\text { al } 20022^{22}\end{array}$ & $\begin{array}{l}\text { USA } \\
\text { Commun } \\
\text { ity }\end{array}$ & 31 & $8-12$ & $\begin{array}{l}\text { OW } \\
(20- \\
100 \% \\
>50 \text { th } \\
\text { BMI } \\
\text { \%ile })\end{array}$ & Positive & $\begin{array}{l}\text { Two delivery methods } \\
\text { (1) PA + FS + DP + } \\
\text { HE + BT (Grp \& Indvid } \\
\text { Sessions) } \\
\text { (2) PA + FS + DP + } \\
\text { HE + BT (Grp Sessions } \\
\text { Only) }\end{array}$ & $\begin{array}{l}20 \text { weeks, } 1 \mathrm{hr} \text { weekly } \\
\text { meetings for } 2 \text { months, } \\
\text { bimonthly meetings for } 2 \\
\text { months, and } 1 \text { monthly } \\
\text { meeting. } \\
20 \text { weeks (end-I, } 83 \% \text {, } \\
69 \% \text { for diet data) }\end{array}$ & Good & $3 \times 24$-hour recall \\
\hline $\begin{array}{l}\text { Reinehr et } \\
\text { al. } 201030\end{array}$ & $\begin{array}{l}\text { Germany } \\
\text { Hospital }\end{array}$ & 66 & Mean 11.5 & $\begin{array}{l}\text { OW } \\
\text { (BMI } \\
>90 \text { th } \\
\leq 97 \text { th } \\
\text { \%ile) } \\
\end{array}$ & Neutral & $\begin{array}{ll}(1) & \text { FS + BT + PA + } \\
\text { HE } & \\
\text { (2) } & \text { WL Control }\end{array}$ & $\begin{array}{l}6 \text { months, Not stated } \\
6 \text { months (end-I, I group } \\
97 \% \text {, C group 86\%) }\end{array}$ & Poor & $\begin{array}{l}\text { 3-day food record, weighed } \\
\text { food data collected. }\end{array}$ \\
\hline $\begin{array}{l}\text { Resnick et } \\
\text { al } \\
2009^{23}\end{array}$ & $\begin{array}{l}\text { USA } \\
\text { School }\end{array}$ & 46 & $\begin{array}{l}\text { grade } \mathrm{K}- \\
5\end{array}$ & $\begin{array}{l}\text { OW/OB } \\
\text { (BMI } \\
\geq 85^{\text {th }} \\
\% \text { ile) }\end{array}$ & Neutral & $\begin{array}{l}\text { Two delivery methods } \\
(1) \quad F S+P A+S B+ \\
\text { NP }+ \text { NS (Education } \\
\text { materials mailed) } \\
(2) \quad F S+P A+S B+ \\
\text { NP }+ \text { NS (Education } \\
\text { materials received through } \\
\text { personal encounters with } \\
\text { CHW's) }\end{array}$ & $\begin{array}{l}\text { I group: } 18 \text { wks (average } \\
3.4 \text { home visits or phone } \\
\text { calls, } 5.5 \text { wks apart). } \\
\text { C group: } 30 \text { wks } 6 \\
\text { mailing contacts over } 30 \\
\text { weeks. intervals) } \\
4 \text { weeks (end-I, } 91 \%)\end{array}$ & Poor & Serves of fruit and vegetable \\
\hline $\begin{array}{l}\text { Rodearmel } \\
\text { et al } 2007 \\
24\end{array}$ & $\begin{array}{l}\text { USA } \\
\text { Universit } \\
\mathrm{y}\end{array}$ & 218 & $7-14$ & $\begin{array}{l}\text { OW/OB } \\
\text { (BMI>8 } \\
5^{\text {th } \% \text { ile })}\end{array}$ & Neutral & $\begin{array}{lc}(1) & \mathrm{FS}+\mathrm{PA}+\mathrm{DP}+ \\
\mathrm{NS}+\mathrm{HE} & \\
(2) & \text { True Control }\end{array}$ & $\begin{array}{l}6 \text { months, Not stated } \\
6 \text { months (end-I, 84\%) }\end{array}$ & Poor & ‘Sweets survey'. \\
\hline $\begin{array}{l}\text { Rolland- } \\
\text { Cachera et } \\
\text { al } 2004^{31}\end{array}$ & $\begin{array}{l}\text { France } \\
\text { Boarding } \\
\text { school at } \\
\text { medical } \\
\text { centre }\end{array}$ & 121 & $11-16$ & $\begin{array}{l}\text { OB } \\
(\text { BMI }>9 \\
7^{\text {th }} \\
\text { French } \\
\text { \%ile) }\end{array}$ & Neutral & $\begin{array}{l}(1) \text { DP (Protein 15\%, } \\
\text { CHO 54\%) + PA + SB } \\
(2) \quad \text { DP (Protein 19\%, } \\
\text { CHO 50\%) + PA + SB }\end{array}$ & $\begin{array}{l}9 \text { months Live in at } \\
\text { boarding school } \\
9 \text { months (end-I, 82\%), } 2 \\
\text { years (FU, 60\%) }\end{array}$ & Poor & Diet provided. \\
\hline $\begin{array}{l}\text { Saelens et } \\
\text { al } 2002^{25}\end{array}$ & $\begin{array}{l}\text { USA } \\
\text { Primary } \\
\text { care }\end{array}$ & 44 & $12-16$ & $\begin{array}{l}\text { OW/OB } \\
(\mathrm{BMI}>2 \\
0-100 \% \\
\text { over } \\
\text { median) }\end{array}$ & Positive & $\begin{array}{l}\text { (1) } \mathrm{BT}+\mathrm{PA}+\mathrm{SB}+ \\
\mathrm{HE}+\mathrm{NE}+\mathrm{P} \\
(2) \quad \mathrm{PA}+\mathrm{HE}\end{array}$ & $\begin{array}{l}16 \text { weeks, I group: } \\
\text { weekly ( } 8 \text { ) and biweekly } \\
\text { (3) phone sessions +mail } \\
\text { C group: } 1 \text { session with } \\
\text { GP } \\
4 \text { months (FU, 88\%),7- }\end{array}$ & Poor & $2 \times 24 \mathrm{hr}$ recall \\
\hline
\end{tabular}




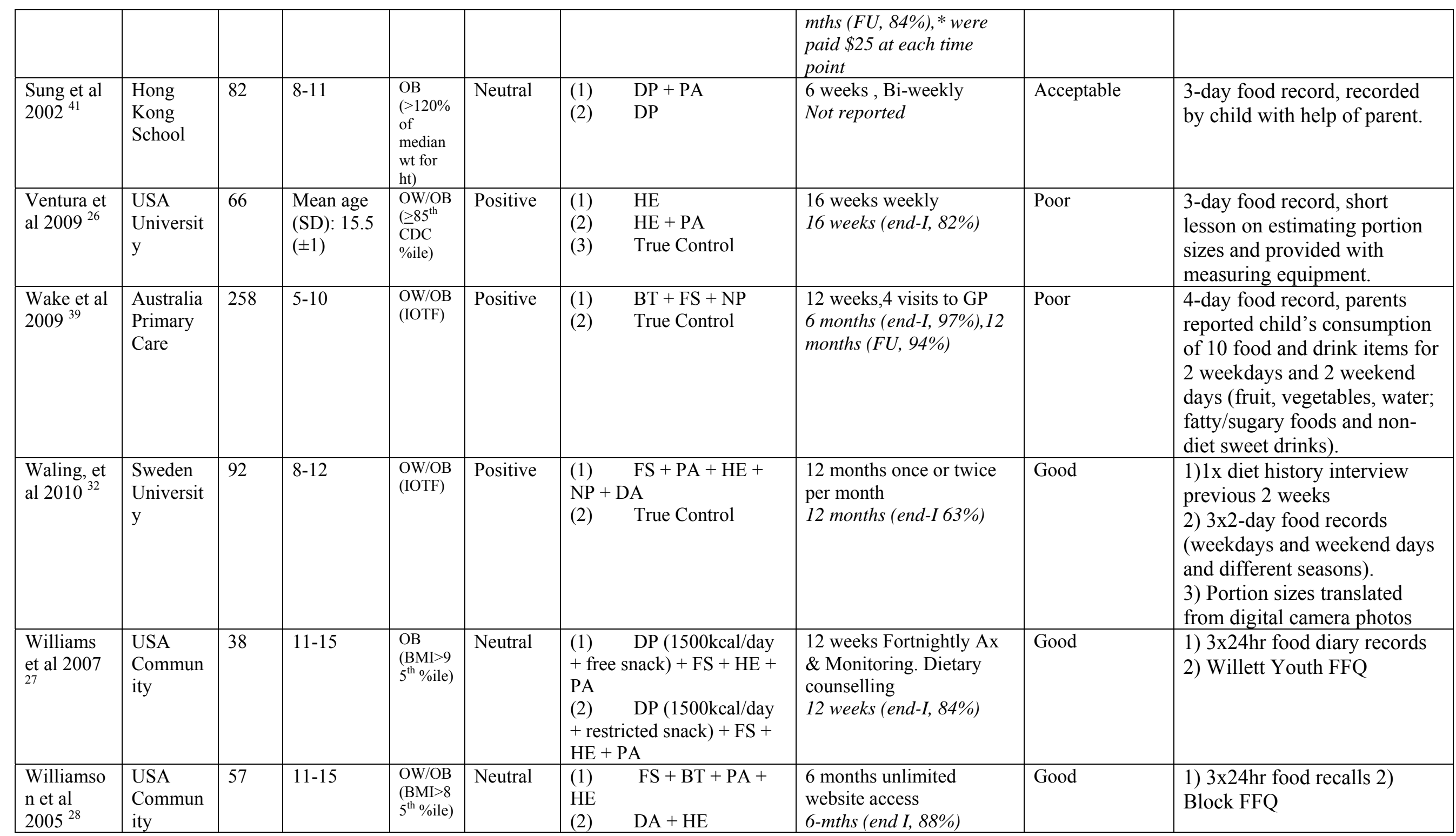


${ }^{1}$ OW overweight; OB obese; CDC Centre for Disease Control; IOTF International Obesity Task Force; \%ile Percentile; ${ }^{2}$ Overall methodological study quality was assessed using the American Dietetic Association critical appraisal tool ${ }^{103}$. Assessed with modified version of the EURECA tool. I -Intervention, FU- Follow up, DPDietary pamphlet, DA- Dietary advice, LSE lifestyle education, DL-Diet and lifestyle, BT-Behaviour therapy, P-Parenting, PA Physical activity, FS - family support SB sedentary behaviour, BMI - Body Mass index, DP-Dietary Prescription, HE-Healthy Eating-, NS Nutrition skills, NE Nutrition environment , NP Nutrition pamphlet, DA- Dietary advice, NO Nutrition other 


\section{FIGURE 1}

Title: Flow diagram of article identification, retrieval and inclusion for systematic review.

\section{FIGURE 2}

Title: Intervention details for randomized controlled trials included in the systematic review.

Legend: Horizontal bars represent the number of studies within each descriptive category. The sections of the horizontal bars starting from left to right by type of dietary instrument used and are represented by the following abbreviations: FD: food diary/record; 24-HR: 24 hour recall; FFQ:

food frequency questionnaire; Q: questionnaire; MM: multiple methods; and Other.

\section{FIGURE 3}

Title: Study and dietary methodology and reporting quality in studies included in the systematic review.

Legend: Horizontal bars represent the number of studies within each descriptive category. The sections of the horizontal bars starting from left to right by type of dietary instrument used and are represented by the following abbreviations: FD: food diary/record; 24-HR: 24 hour recall; FFQ:

food frequency questionnaire; Q: questionnaire; MM: multiple methods; and Other. 


\section{References}

1 Collins C, Watson J, Burrows T. Measuring dietary intake in children and adolescents in the context of overweight and obesity. Int J Obes. 2010; 34: 1103-15.

2 WCRF. World Cancer Research Fund/American Institute for Cancer Research. Food, nutrition, physical activity and prevention of cancer: a global perspective Washington DC, 2007.

3 WHO. World Health Organisation.Obesity: Preventing and Managing the Global Epidemic. WHO Technical Report Series 894: Geneva. 2000.

4 Collins C, McCoy P, Neve M, Stokes B, Warren J. Measuring Effectiveness of Dietetic Interventions in Child Obesity: A systematic review of randomized trials. Arch Peds Adol Med. 2006; 160: 906-22.

5 Magarey A, Watson J, Golley R, et al. Assessing dietary intake in children and adolescents: considerations and recommendations for obesity research. Int J Ped Obes.. 2011; 6: 2-11.

6 Willett W. Nutritional Epidemiology. 2nd edn. New York: Oxford University Press 1998.

7 Nelson M, Margetts, BM., Black, AE. Checklist for the methods section of dietary investigations. Metabolism. 1993; 42: 258-59.

8 Serra-Majem L, Frost-Anderson L, Henriquez-Sanchez P. Evaluating the quality of dietary intake validation studies. Br J Nutr 2009; 102: S3-S9.

9 Moher D, LIberati A, Tetzlaff J, Altman D. Preferred reporting items for systematic reviews and meta analysis: the PRISMA statement. BMJ 2009; 339: 332-39.

10 American Dietetic Assoication. Evidence Analysis Manual; steps in the ADA Evidence Analysis Process. Scientific Affairs and Research.: Chicago 2008; P43-48.

11 Albala C, Ebbeling, CB., Cifuentes, M., Lera, L., Bustos, N., Ludwig, DS. Effects of replacing the habitual consumption of sugar-sweetened beverages with milk in Chilean children. Am J Clin Nutr. 2008; 88: 605-11. 
12 Davis J, Kelly L, Lane C, et al. Randomized control trial to improve adiposity and insulin resistance in overweight Latino adolescents. Obesity 2009; 17: 1542-48.

13 Davis J, Tung A, Chak S, et al. Aerobic and strength training reduces adiposity in overweight Latina adolescents. Medicine \& Science in Sports and Exercise. 2009; 9: 1494-503. 14 Ebbeling C, Leidig, MM., Sinclair, KB., Hangen, JP., Ludwig, DS. . A reduced-glycemic load diet in the treatment of adolescent obesity. Arch Pediatr Adolesc Med. 2003; 157: 773-79. 15 Ebbeling C, Feldman, HA., Osganian, SK., Chomitz, VR., Ellenbogen, SJ., Ludwig, DS. Effects of decreasing sugar-sweetened beverage consumption on body weight in adolescents: A randomized, controlled pilot study. Pediatrics. 2006; 117: 673-80.

16 Ellis D, Janisse, H., Naar-King, S., Kolmodin, K., Jen, KLC., Cunningham, P., Marshall, S. . The effects of multisystemic therapy on family support for weight loss among obese AfricanAmerican adolescents: Findings from a randomized controlled trial. J Dev Behav Pediatr 2010; 31 : $461-68$.

17 Epstein L, Roemmich J, Robinson J, et al. A randomized trial of the effects of reducing television viewing and computer use on body mass index in young children. Arch Pediatr Adolesc Med. 2008; 162: 239-45.

18 Goldfield G, Mallory R, Parker T, et al. Effects of open-loop feedback on physical activity and television viewing in overweight and obese children: A randomized, controlled trial. Pediatrics 2006; 118: 157-66.

19 Gutin B, Barbeau P, Owens S, et al. Effects of exercise intensity on cardiovascular fitness, total body composition, and visceral adiposity of obese adolescents. Am J Clin Nutr. 2002; 75: 81826.

20 Janicke D, Sallinen B, Perri M, et al. Comparison of parent-only vs family-based interventions for overweight children in underserved rural settings:Outcomes from project STORY. Arch Pediatr Adolesc Med. 2008; 162: 1119-25. 
21 Krebs N, Gao, D., Gralla, J., Collins, JS., Johnson, SL. . Efficacy and safety of a high protein, low carbohydrate diet for weight loss in severely obese adolescents. J Pediatr 2010; 157 : 252-58.

22 Raynor H, Kilanowski, CK., Esterlis, I., Epstein, LH. A cost-analysis of adopting a healthful diet in a family-based obesity treatment program. J Am Diet Assoc. 2002; 102: 645-56. 23 Resnick E, Bishop M, O'Connell A, et al. The CHEER study to reduce BMI in elementary school students: A school-based, parent-directed study in Framingham, Massachusetts. The Journal of School Nursing. 2009; 25: 361-72.

24 Rodearmel S, Wyatt, HR., Stroebele, N., Smith, SM., Ogden, LG., Hill, JO Small changes in dietary sugar and physical activity as an approach to preventing excessive weight gain: The America on the Move Family Study. Pediatrics. 2007; 120: 869-79.

25 Saelens B, Sallis, JF., Wilfley, DE., Patrick, K., Cella, JA., Buchta, R. Behavioral weight control for overweight adolescents initiated in primary care. Obesity Research. 2002; 10: 22-32. 26 Ventura E, Davis J, Byrd-Williams C, et al. Reduction in risk factors for type 2 diabetes mellitus in response to a low-sugar, high-fiber dietary intervention in overweight latino adolescents. Arch Pediatr Adolesc Med. 2009; 163: 320-27.

27 Williams C, Strobino, BA., Brotanek, J. . Weight control among obese adolescents: A pilot study. Int J Food Sci Nutr. 2007; 58: 217-30.

28 Williamson D, Martin P, White M, et al. Efficacy of an internet-based behavioral weight loss program for overweight adolescent African-American girls. Eating Weight Disord. 2005; 10: 193-203.

29 Ford A, Bergh, C., So“dersten, AB., Sabin, MA., Hollinghurst, S., Hunt, LP., Shield, JPH. . Treatment of childhood obesity by retraining eating behaviour: randomised controlled trial. BMJ 2010; 340: doi: 10.1136/bmj.b5388 
30 Reinehr T, Schaefer, A., Winkel, K., Finne, E., Toschke, AM., Kolip, P. An effective

lifestyle intervention in overweight children: Findings from a randomizedcontrolled trial on“'Obeldickslight”. Clinical Nutrition. 2010; 29: 331-36.

31 Rolland-Cachera M, Thibault, H., Souberbielle, JC., Soulie, D., Carbonel, P., Deheeger, M., Roinsol, D., Longueville, E., Bellisle, F., Serog, P. Massive obesity in adolescents: dietary interventions and behaviours associated with weight regain at 2 y follow-up. Int J Obes. 2004; 28 : $514-19$.

32 Waling M, Lind, T., Hernell, O., Larsson, C. A one-year intervention has modest effects on energy and macronutrient intakes of overweight and obese Swedish children. J Nutr. 2010; 140: $1793-98$.

33 Garipağaoğlu M, Sahip Y., Darendeliler, F., Akdikmen, O., Kopuz, S., Sut, N. Family-based group treatment versus individual treatment in the management of childhood obesity: randomized, prospective clinical trial. Eur J Pediatr. 2009; 168: 1091-99.

34 Gillis D, Brauner, M., Granot, E. A community-based behavior modification intervention for childhood obesity. J Pediatr Endocrinol Metab. 2007; 20: 197-203.

35 Nemet D, Barkan, S., Epstein, Y., Friedland, O., Kowen, G., Eliakim, A. . Short- and longterm beneficial effects of a combined dietary-behavioral-physical activity intervention for the treatment of childhood obesity. Pediatrics 2005; 115: e443-e49.

36 Nemet D, Berger-Shemesh, E., Wolach, B., Eliakim, A. A combined dietary-physical activity intervention affects bone strength in obese children and adolescents. Int J Sports Med 2006; 27: 666-71.

37 Burrows T, Warren, JM., Baur, LA., Collins, CE. Impact of a child obesity intervention on dietary intake and behaviors. Int J Obes. 2008; 32: 1481-88.

38 McCallum Z, Wake M, Gerner B, et al. Outcome data from the LEAP (Live, Eat and Play) trial: a randomized controlled trial of a primary care intervention for childhood overweight/mild obesity. Int J Obes. 2007; 31: 630-36. 
39 Wake M, Baur L, Gerner B, et al. Outcomes and costs of primary care surveillance and intervention for overweight or obese children: the LEAP 2 randomised controlled trial. BMJ. 2009; 339: b3308.

40 Park T, Hong, HY., Lee, J., Kang, BS. Lifestyle plus exercise intervention improves metabolic syndrome markers without change in adiponectin in obese girls. Ann Nutr Metab. 2007; 51: 197-203.

41 Sung R, Yu, CW., Chang, SKY., Mo, SW., Woo, KS., Lam, CWK. Effects of dietary intervention and strength training on blood lipid level in obese children. Arch Dis Child 2002; 86: 407-10.

42 Thompson F, Byers T. Dietary assessment resource manual J Nutr. 1994: 2245S-318S.

43 Burrows T, Golley R, Collins C, Magarey AM. Development of an online decision tool to guide dietary intake methdology selection. Nutrition and Dietetics. 2010; 67: 3.

44 Nelson M, Margetts, BM., Black, AE. Editorial guidelines for the methods section of dietary investigations. Diabetologia 1994; 37: 222-23.

45 Nelson M, Margetts B, Black A. The validation of dietary assessment., in Design concepts in nutritional epidemiology. New York: Oxford University Press 1997.

46 deMoor C, Baranowski T, Cullen K, Nicklas T. Misclassification associated with measurement error in the assessment of dietary intake. Public Health Nutrition. 2003; 6: 393-99.

47 Moher D, Cook, DJ., Eastwood, S., Olkin, I., Rennie, D., et al. for the QUOROM group Improving the quality of reporting of meta-analysis of randomized controlled trials: The QUOROM statement. . Lancet. 1999; 354: 1896-900.

48 PRISMA. Preferred reporting items for systematic reviews and meta-analyses. http://wwwprisma-statementorg/. Accessed February 14, 2012.

49 Des Jarlais D, Lyles, C., Crepaz, N. . Improving the Reporting Quality of Nonrandomized Evaluations of Behavioral and Public Health Interventions: The TREND Statement. Am J Public Health. 2004; 94: 361-66. 
50 Daugherty B, Schap T, Ettienne-Gittens S, et al. Novel Technologies for assessing dietary intake: evaluating the usability of a mobile telephone food record among adults and adolscents. $J$ Med Internet Res. 2012; 14: e58.

51 Boushey C, Kerr D, Wright J, Lutes K, Ebert D, Delp E. Use of technology in childrens dietary assessment. Eur J Clin Nutr 2009; 63: s50-57.

52 ACAORN. Dietary intake assessment tool

http://sydney.edu.au/medicine/acaorn/streams/nutrition/index.php.: 2010.

53 MRC. Dietary assessment http://toolkit.s24.net/dietary-assessment/index.html. Medical

Research Council.: 2010. 


\section{FIGURE 1}

Title: Flow diagram of article identification, retrieval and inclusion for systematic review.

\section{FIGURE 2}

Title: Intervention details for randomized controlled trials included in the systematic review.

Legend: Horizontal bars represent the number of studies within each descriptive category. The sections of the horizontal bars starting from left to right by type of dietary instrument used and are represented by the following abbreviations: FD: food diary/record; 24-HR: 24 hour recall; FFQ:

food frequency questionnaire; Q: questionnaire; MM: multiple methods; and Other.

\section{FIGURE 3}

Title: Study and dietary methodology and reporting quality in studies included in the systematic review.

Legend: Horizontal bars represent the number of studies within each descriptive category. The sections of the horizontal bars starting from left to right by type of dietary instrument used and are represented by the following abbreviations: FD: food diary/record; 24-HR: 24 hour recall; FFQ:

food frequency questionnaire; Q: questionnaire; MM: multiple methods; and Other. 
Figure 1

Flow diagram of article identification, retrieval and inclusion for the systematic review
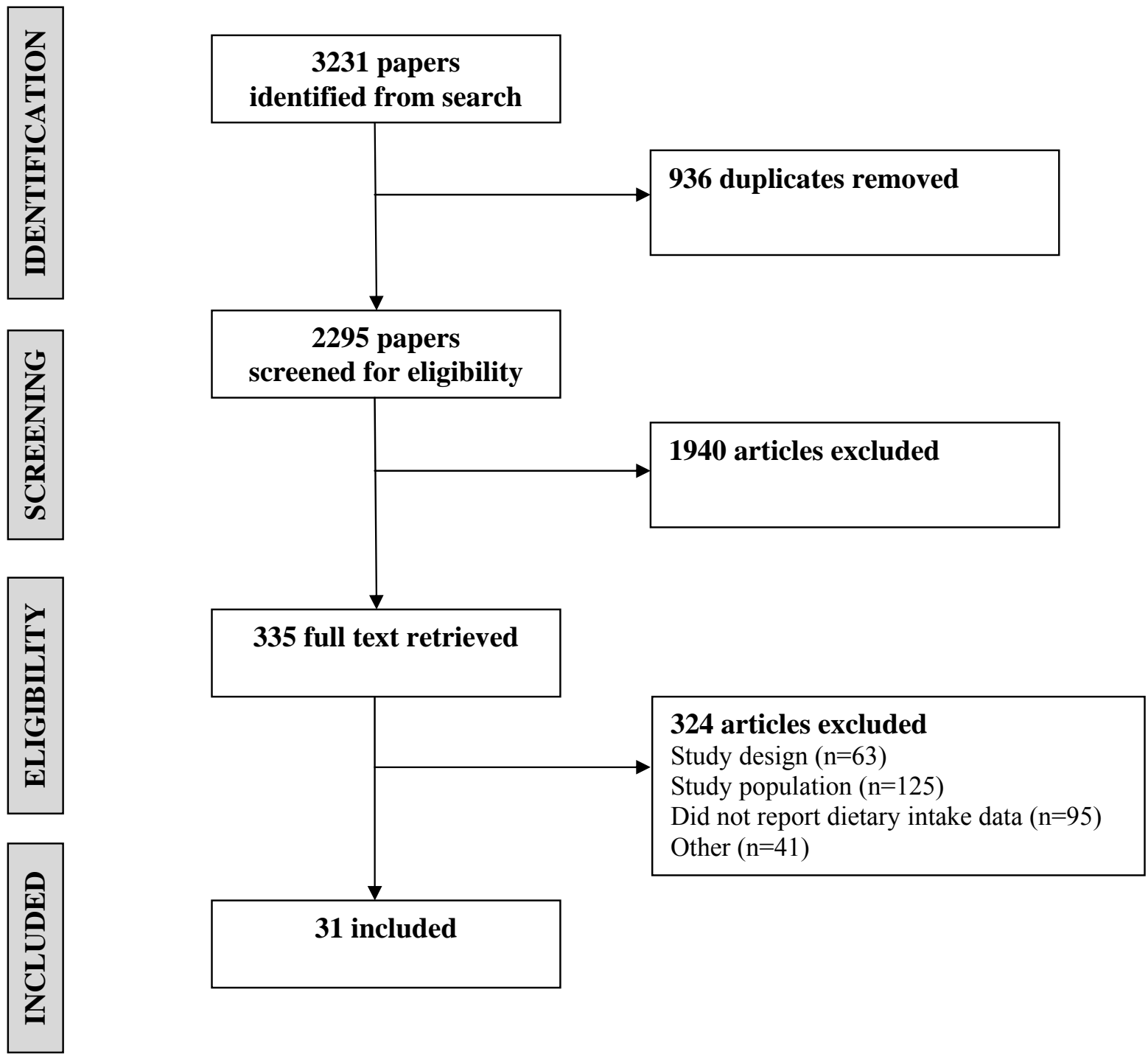

31 included 
Figure 2

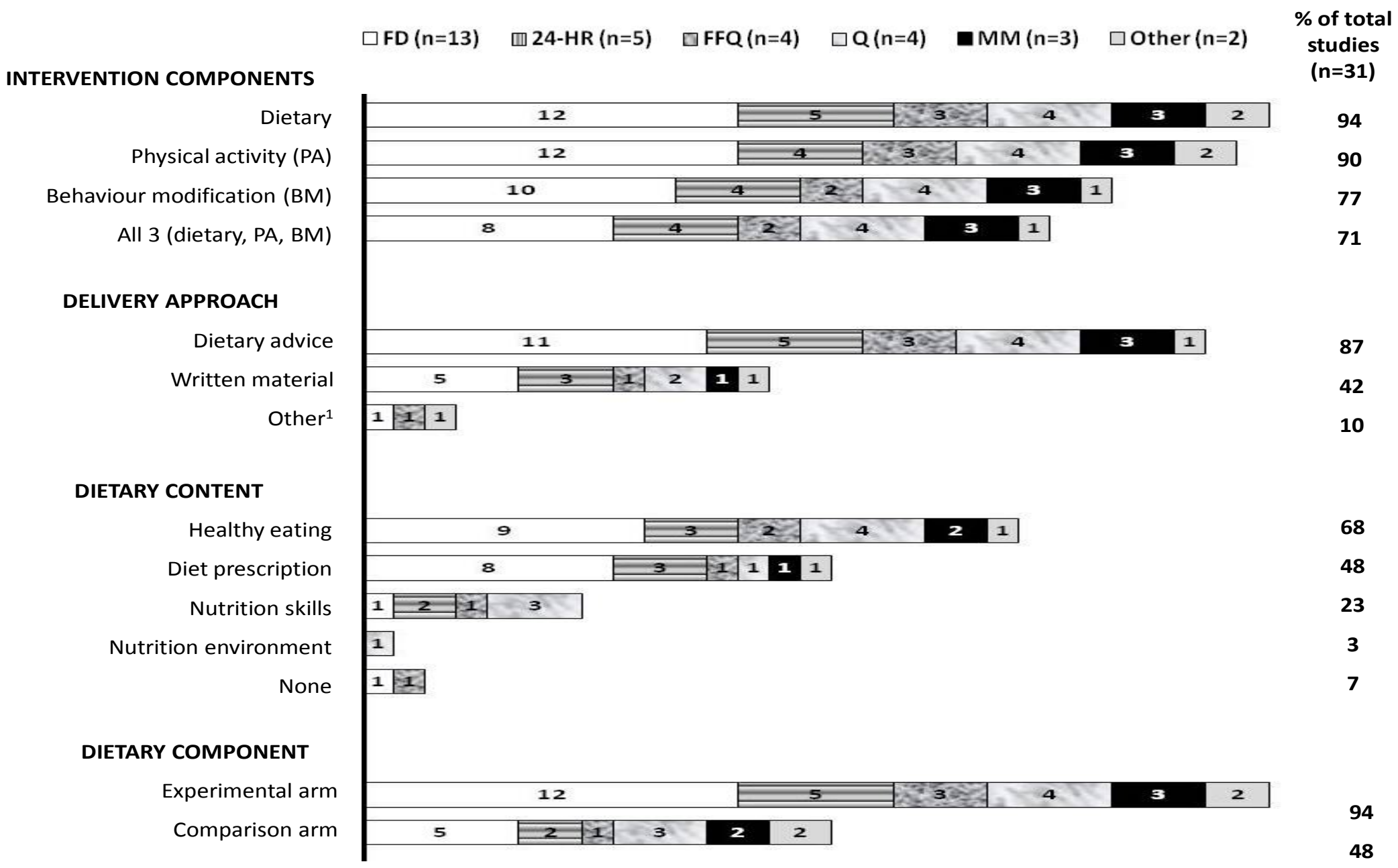

${ }^{1}$ Other represents studies that did not have a dietary component, such as Goldfield, 2006 and Epstein, 2008 which aimed to reduce sedentary behaviour and increase physical activity and the study by Reinehr, 2010 that reported approaches varied by treatment center. 
Figure 3

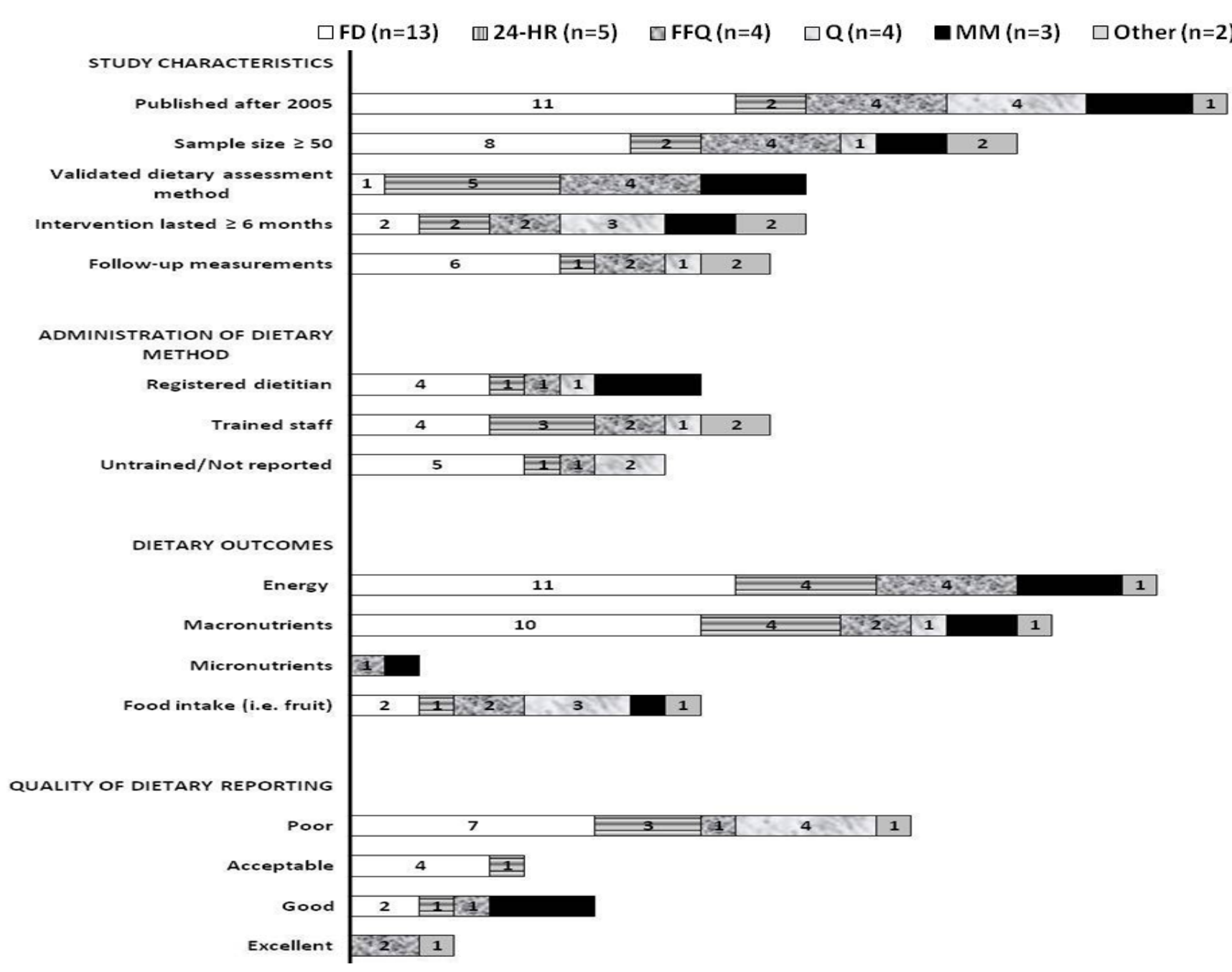

$\%$ of total studies ( $n=31$ )

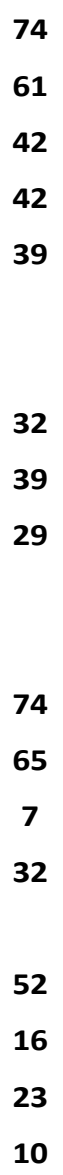


Table S1: Full search Strategy for The quality of dietary intake methodology and reporting in child and adolescent obesity intervention trials: a systematic review.

\begin{tabular}{|c|c|c|c|c|c|c|}
\hline $\begin{array}{l}\text { Set } \\
\text { No. }\end{array}$ & Search terms & $\begin{array}{l}\text { MEDLINE } \\
\text { Results }\end{array}$ & $\begin{array}{l}\text { CINAHL } \\
\text { Results }\end{array}$ & $\begin{array}{l}\text { EMBASE } \\
\text { Results }\end{array}$ & $\begin{array}{l}\text { MEDLINE } \\
\text { In process }\end{array}$ & $\begin{array}{l}\text { PsycINFO } \\
\text { Results }\end{array}$ \\
\hline 1 & dietetic*.mp. & 8172 & 3307 & 12,144 & 131 & 335 \\
\hline 2 & diet.mp. & 241482 & 47190 & 280,797 & 5324 & 11969 \\
\hline 3 & nutrition.mp. & 118362 & 47024 & 1,183 & 3538 & 9226 \\
\hline 4 & healthy eating.mp. & 118362 & 1205 & 2,164 & 112 & 720 \\
\hline 5 & dietary intervention*.mp. & 2688 & 792 & 695 & 143 & 284 \\
\hline 6 & 1 or 2 or 3 or 4 or 5 & 342064 & 84760 & $1,227,043$ & 8672 & 20432 \\
\hline 7 & paediatric*.mp. & 28147 & 7067 & 120,978 & 1564 & 1792 \\
\hline 8 & pediatric*.mp. & 161296 & 52346 & 566,058 & 1564 & 1792 \\
\hline 9 & child*.mp. & 1590971 & 303446 & $1,288,904$ & 23079 & 466018 \\
\hline 10 & adolescent*.mp. & 1388461 & 43047 & 559,159 & 4597 & 132729 \\
\hline 11 & family.mp. & 561866 & 104645 & 675,294 & 14987 & 199344 \\
\hline 12 & families.mp. & 127595 & 29846 & 107,715 & 4528 & 81218 \\
\hline 13 & parent*.mp. & 279039 & 63957 & 275,855 & 9360 & 168525 \\
\hline 14 & school*.mp. & 175456 & 68860 & $2,163,246$ & 6022 & 279945 \\
\hline 15 & $\begin{array}{l}7 \text { or } 8 \text { or } 9 \text { or } 10 \text { or } 11 \text { or } \\
12 \text { or } 13 \text { or } 14\end{array}$ & 2976411 & 461805 & $3,899,441$ & 50814 & 827648 \\
\hline 16 & overweight.mp. & 23171 & 6751 & 22,543 & 1477 & 5450 \\
\hline 17 & obesity.mp. & 131109 & 33961 & 158,206 & 4470 & 14367 \\
\hline 18 & weight control*.mp. & 3435 & 5025 & 4,020 & 176 & 3939 \\
\hline 19 & weight management.mp. & 1396 & 1001 & 1,552 & 123 & 730 \\
\hline 20 & weight loss.mp. & 44918 & 11375 & 39,007 & 0 & 5725 \\
\hline 21 & healthy weight.mp. & 581 & 666 & 529 & 54 & 250 \\
\hline 22 & $\begin{array}{l}16 \text { or } 17 \text { or } 18 \text { or } 19 \text { or } \\
20 \text { or } 21 \text { or } 22\end{array}$ & 169560 & 45431 & 188,244 & 5261 & 20822 \\
\hline 23 & intervention*.mp. & 383208 & 126899 & 147,761 & 18483 & 167377 \\
\hline 24 & $\begin{array}{l}\text { randomized controlled } \\
\text { trial.pt. }\end{array}$ & 299648 & 16671 & 206,899 & 411 & 4334 \\
\hline 25 & controlled clinical trial.pt. & 82502 & 82055 & 294,392 & 21 & 660 \\
\hline 26 & randomized.ab. & 206014 & 35450 & 79,525 & 8235 & 23257 \\
\hline 27 & placebo.ab. & 122093 & 16107 & 30,342 & 3378 & 23595 \\
\hline 28 & randomly.ab. & 149770 & 22961 & 41,377 & 8502 & 38440 \\
\hline 29 & trial.ab. & 212881 & 35197 & 66,369 & 8682 & 44223 \\
\hline 30 & groups.ab. & 997303 & 104934 & 238,861 & 47929 & 284143 \\
\hline 31 & $\begin{array}{l}24 \text { or } 25 \text { or } 26 \text { or } 27 \text { or } \\
28 \text { or } 29 \text { or } 30\end{array}$ & 1463100 & 211252 & 597,540 & 63093 & 366197 \\
\hline 32 & $\begin{array}{l}6 \text { and } 15 \text { and } 22 \text { and } 23 \\
\text { and } 31\end{array}$ & 732 & 233 & 983 & 48 & 151 \\
\hline 33 & $\begin{array}{l}\text { limit } 32 \text { to yr="1985 - } \\
\text { Current" }\end{array}$ & 722 & 233 & 983 & 48 & 150 \\
\hline
\end{tabular}

\section{Cochrane Library}

(dietetic*:ab or diet:ab or nutrition:ab or healthy eating:ab or dietary intervention*:ab) and (paediatric*:ab or pediatric:ab or child*:ab or adolescent*:ab or family:ab or families:ab or parent*:ab or school*:ab) and (overweight:ab or obesity:ab or weight control*:ab or weight management:ab or weight loss:ab or healthy weight:ab) and (randomised control trial:ab or randomized control trial:ab or controlled clinical trial or (placebo:ab) or (randomly.ab) or (trial.ab) or (groups.ab)) and intervention*:ab 
Topic $=\left(\right.$ dietetic $^{*}$ or diet or nutrition or healthy eating or dietary intervention* $)$ AND Topic $=($ paediatric $*$ or pediatric* or child* or adolescent* or family or families or parent* or school*) AND Topic=(overweight or obesity or weight control* or weight management or weight loss or healthy weight) AND

Topic $=($ randomized control trial or randomised control trial or controlled clinicial trial or randomized or placebo or randomly or trial or groups) AND Title=(intervention*)

\section{SCOPUS - 676}

ABS((dietetic* OR diet OR nutrition OR "healthy eating" OR "dietary intervention*") AND (paediatric* OR pediatric OR child* OR adolescent* OR family OR families OR parent* OR school*) AND (overweight OR obesity OR "weight control*" OR "weight management" OR "weight loss" OR "healthy weight") AND ("randomised control trial" OR "randomized control trial" OR "controlled clinical trial" OR (placebo) OR (randomly) OR (trial) OR (groups)) AND intervention*)

\section{Dissertations and Theses}

145 documents found for: (dietetic* OR diet OR nutrition OR "healthy eating" OR "dietary intervention*") AND (paediatric* OR pediatric OR child* OR adolescent* OR family OR families OR parent* OR school*) AND (overweight OR obesity OR "weight control*" OR "weight management" OR "weight loss" OR "healthy weight") AND ABS("randomised control trial" OR "randomized control trial" OR "controlled clinical trial" OR (placebo) OR (randomly) OR (trial) OR (groups)) AND (intervention*)

\section{$A D T=0$}

((dietetic* OR diet OR nutrition OR "healthy eating" OR "dietary intervention*") AND (paediatric* OR pediatric OR child* OR adolescent* OR family OR families OR parent* OR school*) AND (overweight OR obesity OR "weight control*" OR "weight management" OR "weight loss" OR "healthy weight") AND ("randomised control trial" OR "randomized control trial" OR "controlled clinical trial" OR (placebo) OR (randomly) OR (trial) OR (groups)) AND (intervention*)) 
Table S2: Dietary intake methodology reporting checklist developed for review

\begin{tabular}{|c|c|}
\hline \multicolumn{2}{|l|}{ All Methods } \\
\hline $\begin{array}{l}\text { Document dietary } \\
\text { assessment method }\end{array}$ & $\begin{array}{l}\text { ie diet recall, diet history, food frequency questionnaire, dietary questionnaire, } \\
\text { (weighed) food record, biomarker (list), other (describe) }\end{array}$ \\
\hline $\begin{array}{l}\text { Is there a referenced } \\
\text { or reported validation } \\
\text { study? }\end{array}$ & If yes, use to complete question $1-2$ \\
\hline $\begin{array}{l}\text { Document dietary } \\
\text { assessment method } \\
\text { validated against }\end{array}$ & $\begin{array}{l}\text { ie diet recall, diet history, food frequency questionnaire, , dietary questionnaire, } \\
\text { (weighed) food record, biomarker (list), other (describe) }\end{array}$ \\
\hline $\begin{array}{l}\text { 1. Validation study } \\
\text { sample \& sample size } \\
\text { (max } 1 \text { point): }\end{array}$ & $\begin{array}{l}0.0 \text { method not validated; } 0.5 \text { if validated in same population as for intervention } \\
\text { study; PLUS } 0.5 \text { if } n \geq 100 \text { or } n \geq 50 \text { if biomarkers used. }\end{array}$ \\
\hline $\begin{array}{l}\text { 2. Statistics to assess } \\
\text { validity ( } \max 3 \\
\text { points) }\end{array}$ & $\begin{array}{l}1.0 \text { if compare/test mean or median or difference or face validity (expert review); } \\
\text { PLUS [choose highest value of: } 0.5 \text { correlation OR } 1.0 \text { adjusted correlations/ } \\
\text { unweighted Kappa/ Cronbach alpha OR } 1.5 \text { deattenuated/ interclass correlations/ } \\
\text { weighted Kappa]; PLUS } 0.5 \text { classification or Bland \& Altman plot). }\end{array}$ \\
\hline 3. Data collection & 0.5 if researcher administered (ie supervised, face to face or phone interview); plus \\
\hline (max 1 point) & 0.5 if conducted or reviewed/checked by a trained person \\
\hline $\begin{array}{l}\text { 4. Scoring Method } \\
\text { (max } 1 \text { point) }\end{array}$ & $\begin{array}{l}\text { 1.0 For questionnaires - weighting of items or subscales reported; } 1.0 \text { For nutrient } \\
\text { calculations -relevant nutrient databases reported }\end{array}$ \\
\hline \multicolumn{2}{|c|}{ FOOD FREQUENCY QUESTIONNAIRE $^{1}$} \\
\hline $\begin{array}{l}\text { 5. Frequency scale } \\
(\max 1 \text { point })\end{array}$ & 0.5 if considered; 0.5 robust portion size estimation methodology \\
\hline $\begin{array}{l}\text { 6. Seasonality ( } \max \\
0.5 \text { points) }\end{array}$ & 0.5 if considered \\
\hline
\end{tabular}

\section{FOOD RECORD/RECALL METHOD}

5. Number of days $\quad 0.5$ for multiple days of recall: 0.5 for consideration of all days of the week (i.e. all recall (max 1 point) days covered at group level or weighting applied to adjust for weekday/weekend day)

6. Use of multiple $\quad(0.25$ if multiple pass protocol used: 0.25 if aids/ prompts used for portion size pass and aids/ estimation)

prompts (additional

0.5 points)

\section{DIET HISTORY}

5. Time-scale ( $\max \quad 0.5$ if time-scale appropriate to capture usual intake

0.5 point)

6. Use of 24-h recall 0.5 if included 24-h recall: 0.5 if aids/ prompts used for portion size estimation and aids/ prompts

(max 1 point)

\section{DIETARY QUESTIONNAIRE ${ }^{1}$}

5. Details provided $\quad 1.0$ point if provided as an appendix OR 0.5 point if summary of items reported.

(max 1 point)

6. Factor analysis $\quad 0.5$ if undertaken

(max 0.5 point)

$\begin{array}{ll}\begin{array}{l}\text { Total Score (max } 7 \\ \text { points) }\end{array} & \geq 5 \text { points (very good/excellent); or } 3.5 \leq \text { score }<5 \text { points (good); } 2.5 \leq \text { score }<3.5 \\ \text { points (acceptable/reasonable); } \leq 2.0 \text { points (poor) }\end{array}$

${ }^{1}$ The term food frequency questionnaire was reserved for questionnaires focusing on assessment of frequency of food intake. 
Table S3: Dietary intake methodology reporting checklist developed for review

\begin{tabular}{|c|c|}
\hline \multicolumn{2}{|l|}{ All Methods } \\
\hline $\begin{array}{l}\text { Document dietary } \\
\text { assessment method }\end{array}$ & $\begin{array}{l}\text { ie diet recall, diet history, food frequency questionnaire, dietary questionnaire, } \\
\text { (weighed) food record, biomarker (list), other (describe) }\end{array}$ \\
\hline $\begin{array}{l}\text { Is there a referenced } \\
\text { or reported validation } \\
\text { study? }\end{array}$ & If yes, use to complete question $1-2$ \\
\hline $\begin{array}{l}\text { Document dietary } \\
\text { assessment method } \\
\text { validated against }\end{array}$ & $\begin{array}{l}\text { ie diet recall, diet history, food frequency questionnaire, , dietary questionnaire, } \\
\text { (weighed) food record, biomarker (list), other (describe) }\end{array}$ \\
\hline $\begin{array}{l}\text { 1. Validation study } \\
\text { sample \& sample size } \\
\text { (max } 1 \text { point): }\end{array}$ & $\begin{array}{l}0.0 \text { method not validated; } 0.5 \text { if validated in same population as for intervention } \\
\text { study; PLUS } 0.5 \text { if } n \geq 100 \text { or } n \geq 50 \text { if biomarkers used. }\end{array}$ \\
\hline $\begin{array}{l}\text { 2. Statistics to assess } \\
\text { validity ( } \max 3 \\
\text { points) }\end{array}$ & $\begin{array}{l}1.0 \text { if compare/test mean or median or difference or face validity (expert review); } \\
\text { PLUS [choose highest value of: } 0.5 \text { correlation OR } 1.0 \text { adjusted correlations/ } \\
\text { unweighted Kappa/ Cronbach alpha OR } 1.5 \text { deattenuated/ interclass correlations/ } \\
\text { weighted Kappa]; PLUS } 0.5 \text { classification or Bland \& Altman plot). }\end{array}$ \\
\hline 3. Data collection & 0.5 if researcher administered (ie supervised, face to face or phone interview); plus \\
\hline$(\max 1$ point $)$ & 0.5 if conducted or reviewed/checked by a trained person \\
\hline $\begin{array}{l}\text { 4. Scoring Method } \\
\text { (max } 1 \text { point) }\end{array}$ & $\begin{array}{l}\text { 1.0 For questionnaires - weighting of items or subscales reported; } 1.0 \text { For nutrient } \\
\text { calculations -relevant nutrient databases reported }\end{array}$ \\
\hline \multicolumn{2}{|c|}{ FOOD FREQUENCY QUESTIONNAIRE ${ }^{1}$} \\
\hline $\begin{array}{l}\text { 5. Frequency scale } \\
(\max 1 \text { point })\end{array}$ & 0.5 if considered; 0.5 robust portion size estimation methodology \\
\hline $\begin{array}{l}\text { 6. Seasonality ( } \max \\
0.5 \text { points) }\end{array}$ & 0.5 if considered \\
\hline
\end{tabular}

\section{FOOD RECORD/RECALL METHOD}

5. Number of days $\quad 0.5$ for multiple days of recall: 0.5 for consideration of all days of the week (i.e. all recall (max 1 point) days covered at group level or weighting applied to adjust for weekday/weekend day)

6. Use of multiple $\quad(0.25$ if multiple pass protocol used: 0.25 if aids/ prompts used for portion size pass and aids/ estimation)

prompts (additional

0.5 points)

\section{DIET HISTORY}

5. Time-scale ( $\max \quad 0.5$ if time-scale appropriate to capture usual intake

0.5 point)

6. Use of 24-h recall $\quad 0.5$ if included 24-h recall: 0.5 if aids/ prompts used for portion size estimation and aids/ prompts

(max 1 point)

\section{DIETARY QUESTIONNAIRE ${ }^{1}$}

5. Details provided $\quad 1.0$ point if provided as an appendix OR 0.5 point if summary of items reported.

(max 1 point)

6. Factor analysis $\quad 0.5$ if undertaken

(max 0.5 point)

$\begin{array}{ll}\begin{array}{l}\text { Total Score (max } 7 \\ \text { points) }\end{array} & \geq 5 \text { points (very good/excellent); or } 3.5 \leq \text { score }<5 \text { points (good); } 2.5 \leq \text { score }<3.5 \\ \text { points (acceptable/reasonable); } \leq 2.0 \text { points (poor) }\end{array}$

${ }^{1}$ The term food frequency questionnaire was reserved for questionnaires focusing on assessment of frequency of food intake. 